\title{
Measuring Well-Being and Progress
}

D’Acci L., (2010). Measuring Well-Being and Progress, Social Indicators Research, Vol 104, n.1, pp. 47-65. DOI:10.1007/s11205-010-9717-1

The final publication is available at http://link.springer.com http://link.springer.com/article/10.1007/s11205-010-9717-1

\begin{abstract}
Well-being is becoming a concept which is more and more involved in any world development consideration. A large amount of work is being carried out to study measurements of well-being, including a more holistic vision on the development and welfare of a country. This paper proposes an idea of well-being and progress being in equilibrium with each other. This is distant from the two extreme positions: poor but happy, and rich then happy; too romantic the first, and reductive the second. After a short explanation on the meaning of Objective and Subjective well-being, we show some interesting relations between economic and social variables, and we propose a new index to measure the well-being and progress of the countries: the Well-being \& Progress Index (WIP). It includes several aspects of well-being and progress, like human rights, economic well-being, equality, education, research, quality of urban environment, ecological behaviours, subjective well-being, longevity, and violent crime. The most frequently used indexes usually only focus on some aspects, like ecology, or economy, or policy, or education, or happiness, and so forth. On the contrary, this new WIP index allows a global and well-balanced vision, thanks to the large range of indicators used, and how representative they are.
\end{abstract}

Keywords: well-being, progress, happiness, quality of life, GDP, humanity development

\section{Introduction}

We can think of the economy as having two different origins: ethics and engineering (Sen (1987). The first probably dates back to Aristotele (Etica Nicomachea), in which goods are imagined in the widest sense. The second is connected to more technical questions, like the functioning of the market or other practical problems ${ }^{1}$.

As time went by, the ethical approach lost importance (Sen 1987), but recently the concept of quality of life is getting more and more relevant in every economic consideration.

A large amount of work is being carried out to study measurements of WellBeing, including a more holistic vision of the development and welfare of a country. Just as an example we can cite some recent journals and societies such as Journal of Happiness Studies, the International Society for Quality of Life Research and its Journal Quality of Life Research, or the International Society for Quality of Life Studies and its Journal Social Indicators Research. Moreover, the monitoring and studies by the World Bank, the World Database of Happiness and the Human Development Reports regarding several indices of development ${ }^{2}$ are certainly noteworthy. Furthermore, the increasing number of conferences and symposiums about Happiness or Well-Being and Economy attests the relevance of these issues. One of the most important among them was the Conference Beyond GDP (European Parliament, 2007 Brussels), where Joaquín Almunia, European

\footnotetext{
${ }^{1}$ Some economists had a more ethical orientation, such as Adam Smith, John Stuart Mill, Karl Marx, Francis Edgeworth; some others a more technical one, like William Petty, François Quesnay, David Ricardo, Augustin Cournot or Léon Walras.

${ }^{2}$ Like the World Development Indicators and the World Development Report.
} 
Commissioner for Economic and Monetary Policy, started his speech using these words: "The range of partners involved in today's conference and the participants that have joined us from all over the world are proof of the importance we now place on finding accurate measurements of societal progress and well being". Later, talking about the typical index used until now to measure progress and welfare, the Gross Domestic Product, he said: "GDP [...] cannot distinguish between activities that have a negative or a positive impact on wellbeing. Also, GDP does not take into account the non-economic factors that add to well being [...] These limitations do not undermine the intrinsic value of GDP per se. But it should not be considered as a benchmark of the overall progress of a society as is sometimes the case. [...] We need to find measures that will complement GDP and build a more nuanced and accurate understanding of economic and societal progress. [...] Gross Domestic Product is an indispensable measure of economic activity that has successfully steered our economies through the post-war period, underpinning the prosperity we enjoy today. However, new challenges of the $21 \mathrm{st}$ century require new statistical instruments. Only this way can we both build our understanding of the shifts in our societies and develop our capacity to respond effectively" 3 .

At the same conference the following words were spoken by the President of the European Commission, José Manuel Durão Barroso, in the opening speech: "Let me give you an example. A decision is made to ban all trade in certain types of precious hardwood to preserve an ecologically important forest. The policy is a great success. The forest is preserved for future generations. The ecosystem, and all the life it supports, is protected. Tourism too is safeguarded. In other words, well-being goes up. But what will be the evaluation of this decision if only measured by GDP? It is difficult, and I'm sure that everyone will agree to make tough decisions that promote long-term well-being, even if the short-term consequence is a drop in GDP"4.

Even the Noble Laureate Simon Kuznets, one of the main originators of GDP, said: "the welfare of a nation can scarcely be inferred from a measure of national income", and almost 30 years later he wrote: "Distinctions must be kept in mind between quantity and quality of growth, between costs and returns, and between the short and long run. Goals for more growth should specify more growth of what and for what" .

\section{Objective and Subjective Well-Being}

Objective well-being is based on observable factors such as richness, health, tangible goods, etc. Subjective well-being is referring to well-being which is psychologically experienced ${ }^{7}$.

In other words, we can not only look at well-being as objective well-being, but also as happiness (subjective well-being), or respectively as material well-being (material utility) and as psychological well-being (psychological utility) ${ }^{8}$.

\footnotetext{
3 Joaquín Almunia, "Measuring progress, true wealth and well being", Conference "beyond GDP", Brussels, 19 November 2007.

${ }^{4}$ José Manuel Durão Barroso, "Beyond GDP - Opening speech", Conference "beyond GDP", Brussels, 19 November 2007.

${ }^{5}$ In his first report to the US Congress in 1934: Simon Kuznets (1934), "National Income, 19291932". 73rd US Congress, 2d session, Senate document no. 124, page 7.

${ }^{6}$ Simon Kuznets (1962), "How To Judge Quality", The New Republic, October 20, 1962.

${ }^{7}$ Kahneman (1994), Easterlin (2001) p. 465, Frey and Stutzer (2002), [it. tr. (2006), pp. 25-40].
} 
So, when we purchase a bike our objective well-being is given by the level of material utility provided by it (greater mobility, a means of exercising, a property that can be sold and therefore receiving some proceeds), while our subjective well-being derives from the answers to several questions such as: "is it my first bike?", "how important is it for my own philosophy of life to have a bike, or to have a beautiful bike?", "how useful is it for me to have this kind of physical activity?", "how fulfilling is it to move/travel in an ecological way?", "how does my new bike compare with my previous one, and with the bikes of people around me?", etc ${ }^{9}$.

\section{Subjective Well-Being}

Money allows people to buy goods (e.g. a nice house, a big modern TV, etc.) which in turn gives them material well-being and provides several opportunities (of travelling, having hobbies, accessing better services as school, health care, etc). However, the happiness we receive from material well-being also depends on several factors such as our past and present ${ }^{10}$ socio-economical conditions and our future goals.

Usually, the richer we become the more we wish for; as a consequence of this, subjective and objective well-being can not increase at the same rate. It seems that the psychological well-being records only the variations of the material wellbeing, and does not take into account its actual level ${ }^{11}$.

Research shows that sometimes, even if the richness of a country improves, the average happiness expressed by its population does not improve ${ }^{12}$. However, from this result we remark that a lot of other relevant research shows a close relation between richness and expressed happiness ${ }^{13}$. Moreover, the database, used by some authors to demonstrate that there is no relation between GDP and happiness,

\footnotetext{
${ }^{8}$ Arrigo and Sordelli (2004). This separation is also close, although does not coincide, to the distinction between stimulation and comfort of Scitovsky in his well known The Joyless Economy (1976).

${ }^{9}$ There is a vast quantity of literature and an important historic debate covering this subject, which is also very topical and relative to different concepts and evaluations of utility and well-being. We refer for example to Sen (1987) for a discussion about rationality, utility and well-being; Kahneman (1994, 2003a) about the connections among utility, rationality and the surrounding situation; the research gathered in Frey and Stutzer (2002) show how happiness is dependent on the surrounding situation.

${ }^{10}$ Independence from the reference (for example, how rich I am at this moment) is the base of the Theory of expected utility of Bernoulli, where the (rational) decider makes choices for the expected utility of future situations. However, in the model, the preferences of the decider remain identical, because the utility does not depend on the present situation. From this originated Bernoulli's model, the modern Theory of Decisions, that conserved the assumption of independence from the reference (so called by Tversky and Kahneman, 1991) in all its future versions.

${ }^{11}$ Kahneman 2006; Easterlin 2001, 1974; Frey and Stutzer 2002; Brickman (1978), Franck R. (1999). For further information about this idea read the first part of paragraph 4.

${ }^{12}$ For the USA during the years 1946-1990 refer to Blanchflower and Oswald (2000), Lane (1998) p. 462; Myers (2000), p. 61; for Japan during the years 1958-1991 refer to Frey and Stutzer (2002) fig.1.3; for China during 1994-2005 refer to Kahneman (2006) fig. 4.

13 Diener (1995) shows a strong relation between richness and expressed happiness when comparing 55 countries; the same strong relation is showed by the research of Veenhoven (1991), of Inglehart (1990) and of Inkeles and Diamond (1986), comparing several countries. Many comparisons among different levels of people's richness in the same country show an equally strong relation between richness and expressed happiness: Easterlin (2000) for the USA 1994; Diener and others (1993) for USA 1981-84; data-base of Euro-Barometer Survey Series (19751991) for Europe (look at Di Tella, MacCulloch, Oswald, 1999).
} 
show evidently that cases are just "cases" but in average almost all the countries becoming richer also become happier ${ }^{14}$.

So, even if the adaptation level theory ${ }^{15}$ (after a certain time, an improvement of our condition - e.g. money - does not produce an increase of happiness), and the aspiration level theory ${ }^{16}$ (my happiness depends on the distance between how much I wish for and how much I have) are historically well known in psychology $^{17}$, a number of research studies show how, in average, richness and expressed happiness are quite close (look at note 13); but this relation is not linear: over a certain level of richness, the improvement of expressed happiness decreases even when the richness continues to improve ${ }^{18}$, thus showing some difference between objective and subjective well-being ${ }^{19}$.

Another kind of psychological well-being is the procedural utility ${ }^{20}$ connected to the happiness we can receive through the process by which we reach a goal (material or immaterial goal). Our feeling of "happiness" also depends on the level of well-being of people around us (how much richer or poorer they are in comparison to $\mathrm{me}^{21}$, or ${ }^{22}$ indeed how much happier/unhappier they are compared to me).

Let us move our focus from the feeling of well-being (both objective and subjective) given by goods. Without doubt, all people know how our happiness ${ }^{23}$ is especially influenced by intangible (but real) factors like love, health, friends,

\footnotetext{
${ }^{14}$ http://worlddatabaseofhappiness.eur.nl/

15 Helson (1964), Brickman and Campbell (1971), Parducci (1995), Frederick and Lowenstein (1999). A different version of the adaptation theory is the idea of the "homeostatic process": even after several modifications in our life condition, our happiness tends to go back to our original level of happiness. It is like our happiness derives more from our genetic predisposition than from events changing our life (Headey and Wearing, 1992).

${ }^{16}$ Irwin (1944), Michalos (1991), Inglehart (1990).

${ }^{17}$ In Economy we can also find this theory, considering the changement of the preferences in the forming of habit (Marshall 1890, Duesenberry 1949, Modigliani 1949, Pollak 1970, Carroll and Weil, 1994).

${ }^{18}$ Diener and others (1993), fig 2 for a comparison between income improvement and expressed happiness in the USA 1981-84; Frey and Stutzer (2002), fig. 1.4, for a similar comparison in the USA 1995; and also Smith (1776) evidence showing how, beyond a certain level, an increase of income is not so useful.

${ }^{19}$ Look also at the research carried out by the research group which has grown up by Bernard van Praag and Arie Kaptyen (1973): Kapteyn and Wansbeek (1982), van Praag and Frijters (1999). They show that the shift of preference toward the high (the more I have got the more I want), "deletes" around $60-80 \%$ of the real well-being coming from increased richness.

${ }^{20}$ Frey, Stutzer (2002); Fray, Benz, Stutzer (2002); Hanh (1984). The literature suggests calling procedural utility the well-being given by the process of reaching the goal (what I should do to achieve my goal of buying a bike), and calling the instrumental utility that one received when we reach the intended goal (buying a new bike). Then the psychological well-being concerns both the final state (how happy it makes me feel to own my new bike) and the procedure; the material wellbeing concerns only the final state.

21 Easterlin (1974, 1995); Veblen (1899); Becker (1974); Frank (1985); Pollak (1976); Duesenberry (1949); Russel (1930) p. 68-69; Kapteyn (2000); Kosicki (1987); Hirsch (1976).

${ }^{22}$ We introduce this "or" just to remind the reader that money does not always mean happiness, even if we also show how strong their connection normally is. As we will illustrate later, the position of this paper does not want to be extreme, thus, we are distant from both the romantic idea of "poor but happy" and from the limited idea of "rich then happy".

${ }^{23}$ Even though the literature often uses the terms "happiness", "well-being", "life satisfaction" interchangeably, in this paper we prefer to use the term "well-being" in the context of global welfare (both objective and subjective well-being), reserving the use of the word "happiness" to emphasize only the psychological contribution in our well-being.
} 
hobbies, social relations, political context, natural environment, ethical or intellectual wishes and aims, etc.

\subsection{The importance of measuring Subjective Well-Being}

The economic theory of the $1930 \mathrm{~s}^{24}$ states a revolutionary change in the utility concept: you can not measure it in a cardinal scale but only in an ordinal scale. Thereafter, the measurement of utility means measuring the relative preference (ordinal scale) between two different goods, graphically represented by the well studied indifference lines. Then, following some given relations, the utility is connected only to the actions of choice. Over the years and after the second world war, this new way to measure the utility becomes a part of the famous new welfare economics for a few reasons, particularly for the low trust of the economists in the real viability of measuring something intangible, like feelings and pleasure, and because this new way is mathematically simpler and more efficient $^{25}$.

In contrast to the idea of thinking about the utility as a wish or preference (what I prefer to choose), it is possible to conceive it as Hedonic experience (how happy I'm feeling in consequence of my previous choice). So, the first way is a "pre-" valuation, the second is a "post-" 26 . Both concepts of utility tend to coincide when a person wishes for more of the things that will give him increased pleasure ${ }^{27}$, which is when he is rational. However, an enormous amount of literature ${ }^{28}$ shows that this consumer theory, based on the presupposition of the rationality, needs some radical changes, because in reality the consumer does not seem very rational.

The utility as a preference (or wish) is often called the decision utility (the utility that we assign to a choice, considering how much this choice will be able to give us "happiness"), while the utility as a Hedonic experienced utility (Kahneman 1994). Some research shows how their real distance opens new views on the (old) concept of rationality ${ }^{29}$.

In order to judge the rationality of a choice we can observe how much the decision maximises the expected "experienced utility", in which Kahneman and Snell (1990) call the foreseen utility. Any small or large errors in our estimated foreseen utility can lead to a lower level of experienced utility than is possible for us. Research remarks how these errors are indeed faults inside our own rationality. For example they can denote a possible divergence between what we think we would like in the future and what we are actually going to like right now. These errors can also indicate several kinds of psychological alterations in our memory of past experiences on which we build our present decisions (Kahneman 1994).

\footnotetext{
${ }^{24}$ Especially the economists who followed the authority of Robbins (1932).

25 Allen (1934) and Hicks (1934) showed how the demand theory works, just using an ordinal scale; a few years later, Samuelson (1938) wrote the general behavioural base for the standard theory, in which is valid the axiom: utility means preference; while Houthakker (1950) and Uzawa (1960) provided the actual shape of the expressed preference theory.

${ }^{26}$ The economic analysis is more connected to the preferences and wishes than to the hedonic experience.

${ }^{27}$ We remind the reader (with Sen 1987 too), that sometimes people can have a goal that does not involve directly a traditional well-being (like more money or more material goods or more power), but that makes them feel happier.

${ }^{28}$ Just as an example we remind the reader the success of the column "Anomalies", present from 1987 in the prestigious Journal of Economic Perspectives, where are showed punctual examples of falsification of the consumer theory.

${ }^{29}$ Look at for example Sen (1987), Kahneman (1994), Simon (1982).
} 
If people are not totally rational, their choices will not always maximise the experienced utility; thus, improving their opportunities (money, etc.) does not necessarily mean an increase in their own experienced utility; so it becomes useful to measure the experienced utility directly (Kahneman 2004).

The other reasons for measuring subjective well-being directly are, as mentioned in the previous section, the various causes of divergence between objective and subjective well-being.

\subsection{Measuring the Subjective Well-Being}

"It is a sensible tradition in economics to rely on the judgment of the person directly involved. People are reckoned to be the best judges of the overall quality of their life" (Frey, Luechinger, 2007). So, it is possible to capture subjective well-being by asking a representative sample of individuals to give a judgment about their overall happiness ${ }^{30}$. We show, as an example, the questions asked in the most important survey carried out: "Taken all together, how would you say things are these says - would you say that you are very happy, pretty happy, or not too happy?" (General Social Surveys); "All things considered, how satisfied are you with your life as a whole these days?" (people can give a score on a scale from 1 - dissatisfied - to 10 - satisfied. World Values Survey); "On the whole, are you very satisfied, fairly satisfied, not very satisfied, or not at all satisfied with the life you lead?" (Eurobarometer Surveys).

Other surveys use multiple-item approaches such as the "Satisfaction With Life Scale" (Diener, Pavot, 1993), which is composed of five questions, rated on a scale from 1 to 7.

Psychological studies (Kahneman 2006, 2004, 1994) show several types of problems that occur when people try to give a global evaluation about their happiness. So Kahneman proposes a method of evaluating the global happiness of a person through a reconstruction of the previous day, by filling out a structured questionnaire: Day Reconstruction Method (DRM). The respondents rate each episode of the previous day in terms of its positive or negative effect (momentary utility), and also indicating how long each episode lasted for. The global "happiness" is then the temporal integral of momentary utility.

This idea of the global day of happiness as a temporal integral of momentary utility comes from the utilitarian Jeremy Bentham (1789) through Francis Ysidro Edgeworth (1881) and Alfred Marshall (1890). This concept was called the experienced utility by Kahneman and it is pretty similar to the process benefits ${ }^{31}$ of Juster, Courant and Dow (1985).

Figure 1 shows some average experienced utility (or Net Affect) scores, concerning some episodes during the day, from the above-mentioned research (Kahneman 2004a) carried out on a sample of 909 employed women in Texas ${ }^{32}$.

\footnotetext{
${ }^{30}$ But remember that this does not mean necessarily that it is possible to capture subjective wellbeing through a survey. In practice it is rather difficult for several reasons, such us difficulties of recollection by respondents on how happy they were at a certain time in the past, difficulties of comparing people, cultures etc.

31 “...direct subjective consequences from engaging in some activities to the exclusion of others... For instance, how much an individual likes or dislikes the activity 'panting one's house', in conjunction with the amount of time one spends in painting the house, is as important a determinant of well-being independent of how satisfied one feels about having a freshly painted house" (Juster, Courant, Dow, 1985).

${ }^{32}$ The respondents rate each episode of the previous day by replying to the question "how did you feel during this episode?". In replying to this question he gives a score from 0 to 6 on some
} 
Research carried out by Leu, Burri and Priester (1997) in Switzerland, on a sample of more than 6000 people, shows, by multiple regression, the correlation among several socio-economic, demographic, institutional variables and the level of life satisfaction (using a scale from 1 to 10). Figure 2 shows the influence of some of these variables, and in this histogram the height of the bar love indicates the difference between the average score of life satisfaction of people who are "married" and of people who are "separated and living alone", keeping constant all the other variables. Health indicates the same kind of comparison but between people with "good health" and "bad health". While money is the comparison between people with "income SFr.5000 and more" and "income less than SFr.2000"; education is between people with "elevated education" and "base education".

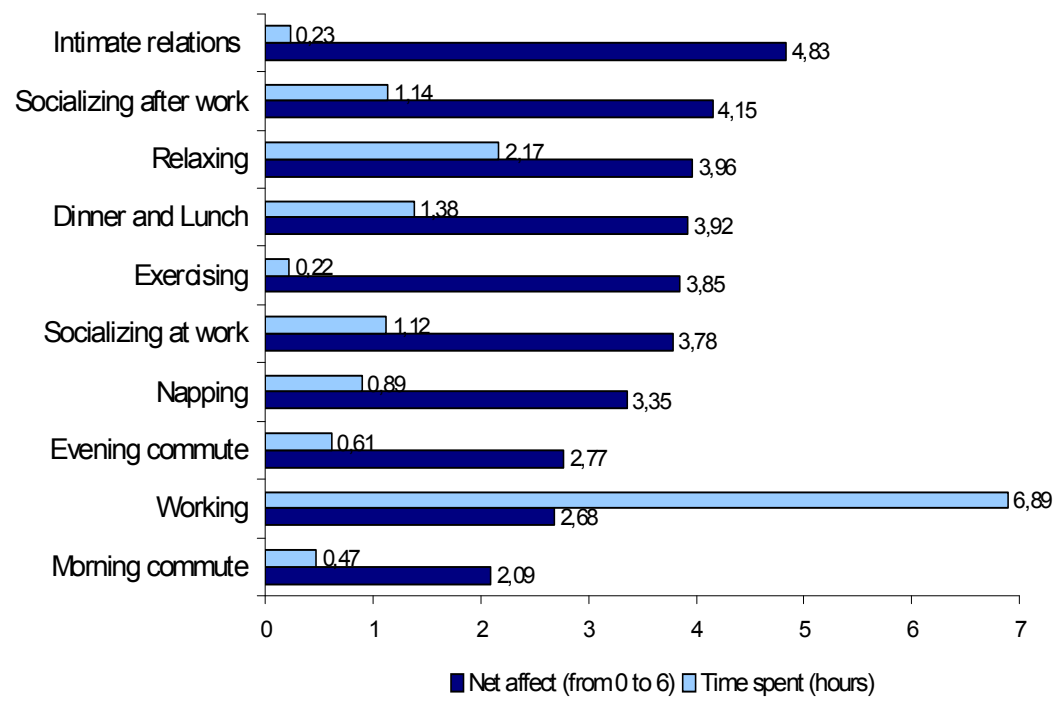

Fig. 1 "Happiness" (Net affect), and Time spent on some activities. Source: elaboration of data from Kahneman and others (2004a).

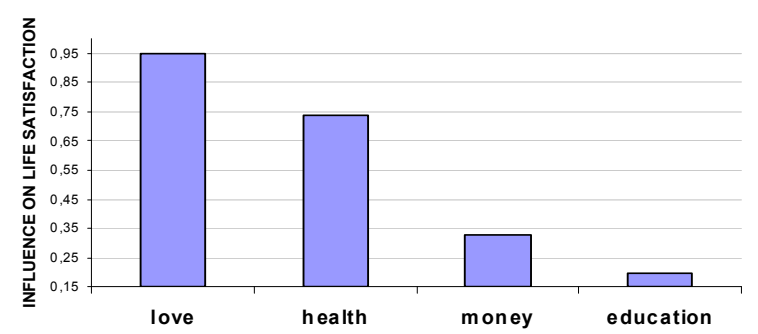

Fig. 2 Influence on life satisfaction. Source: figures elaborated by multiple regression dataset in Leu, Burri, Priester (1997

\section{Objective Well-Being: its importance and measurement}

Considering (or not) all the differences between objective and subjective wellbeing, rapidly shown in this work up until this point in time, a relevant number of research studies (look at note 13) clearly indicate how strong the relation between

possible feelings (happy, frustrated/bored, depressed/sad, annoyed/frightened, tender/cordial, irritated/vexed, worried/anxious, amused, tired), where 0 indicates that the relative feeling was not felt at all, and 6 indicates that the respondents experienced that feeling very much. The Net Affect is the mean of the scores of the positive feelings minus the mean of the scores of the negative feelings. 
richness and expressed happiness is, even if this relation is not as linear as figure 3 shows.

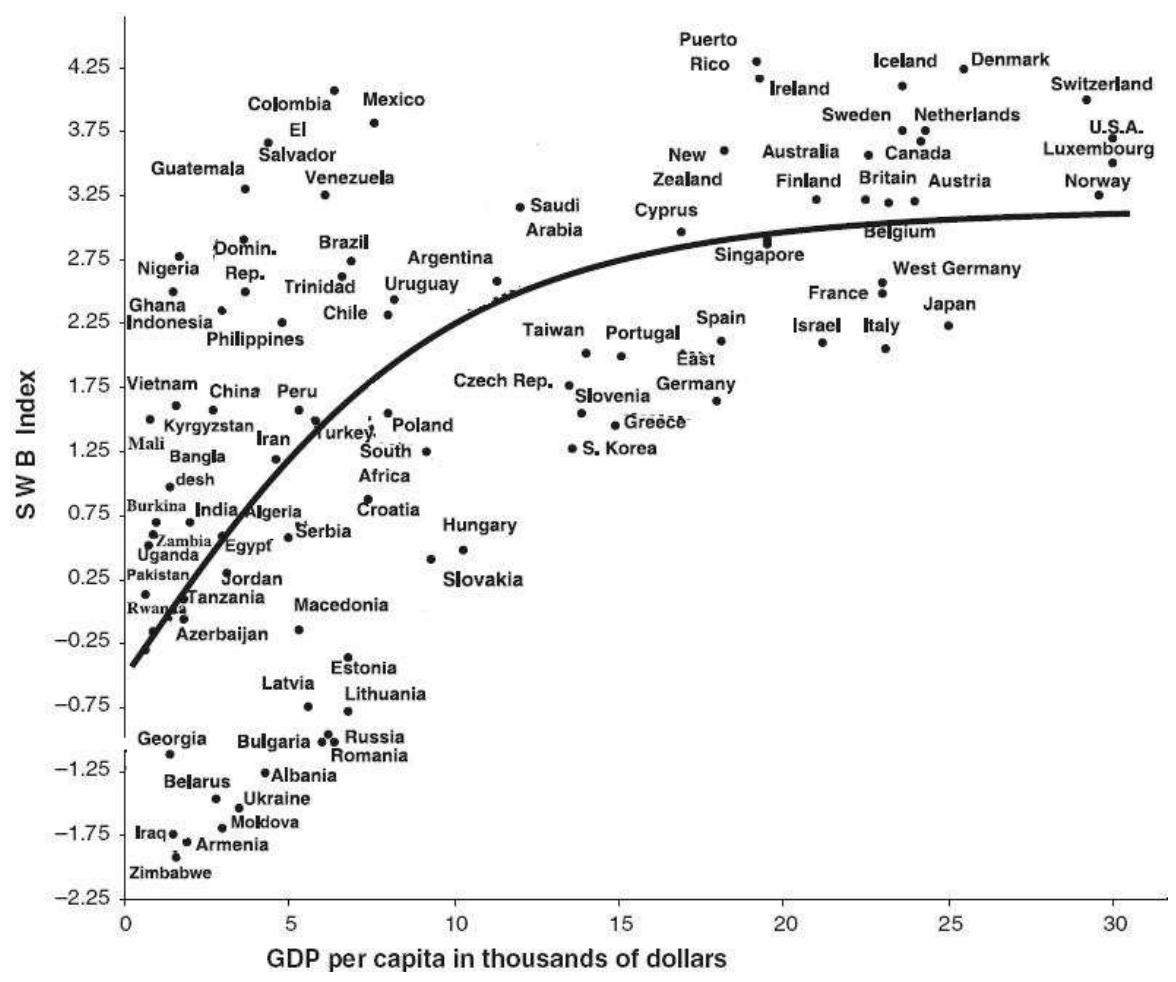

Fig. 3 Subjective well-being (SWB), per capita gross domestic product (GDP) PPP=purchasing power parity estimates. Well-being index is based on reported life satisfaction and happiness, using mean results from all available surveys conducted during 1995-2007 (cubic curve plotted; r5.62). Source: elaboration from Inglehart R., Foa R., Peterson P., Welzel C. (2008), fig.2, p.269.

However, even if we want to consider the results of other research which shows how an increase of richness does not correspond to an increase in happiness (expressed), we provide evidence that, at the very least it does not decrease, but on average $^{33}$ stays the same (look at note 12 too). We believe that, with the same expressed happiness, it is better to be rich than poor. Maybe, the problem would be if the expressed happiness was systematically decreasing while the richness increased, but this situation was not evidenced.

A relation is also presented between GDP per capita and life expectancy at birth (Fig. 4). Although longevity depends on several reasons like the health system, life style (type of food, sport, daily stress, etc), pollution, climate, genetic predisposition of the population, and so forth ${ }^{34}$, the relation between GDP/pop and longevity is evident, and means: (a) that the other variables (climate, life style, pollution...) also are connected to GDP/pop; or (b) that, if the other variables are

\footnotetext{
${ }^{33}$ Except the case of China, (for China during the period 1994-2005 look at Kahneman 2006, fig. 4) and of others countries (Internet appendix to Inglehart, Foa and Welzel, "Social Change, Freedom and Rising Happiness," Journal of Personality and Social Psychology), that show a little decrease of expressed happiness.

${ }^{34}$ It would be interesting to study these relations by means of multiple regression (or similar), to quantify the effect of each of these variables previously measured by a comparative scale, for example.
} 
not connected to GDP/pop, anyway, this last is one of the predominant explicative variables of the life expectancy at birth ${ }^{35}$.

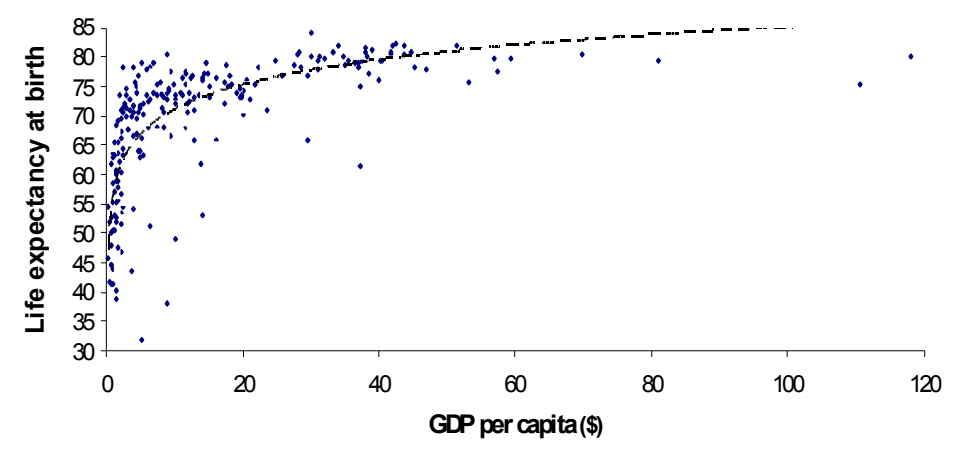

Fig. 4 GDP per capita and Life expectancy at birth (2009) in 224 countries. Source: elaboration from CIA database (www.cia.gov)

Maybe, the right question is whether longer life means a better life too in the richest countries. With regard to this problem, we can see that the quality of life is also usually better in the richest countries. However, this is not always the case, and therefore it is useful to include other variables (objective and subjective) to get a reasonable measure of global well-being.

In this paper, as sources of objective well-being, we intend every aspect to be directly or indirectly physically measurable, like economic richness (GDP, income), longevity (average death age), health (number of pathologies, etc.), pollution, life quality in cities (criminality, percentage of green, traffic, transport, distribution of beauties and amenities ${ }^{36}$, etc.), level of human rights (the condition of women, hours of work, freedom, etc...), national healthy life style (sport practice, drinking/smoking culture, unhealthy alimentary habit, etc.), education (number of universities, average level of study, etc.), and so forth.

\section{Proposal of a Well-Being \& Progress Index}

The purpose of this paper is to propose an equilibrate idea of well-being. This is far from the two extreme positions: poor but happy, and rich then happy; the first being too romantic, and the second being reductive. Moreover, it does not want to evaluate well-being by giving too much priority to subjective well-being or to objective well-being.

Imagine subjective well-being as our own real feeling of happiness set independently from our objective well-being (material, such as money, and not material, such as love, health...). The same level of objective well-being (the same richness, the same love situation, the same level of health...), passing through our mind, will make us feel more or less happy (becoming subjective well-being), dependent on our underground genetic predisposition to be happy, personal life priority, culture, our past and present condition, the general wellbeing of people who are more or less close to us, our life goals, etc.

\footnotetext{
${ }^{35}$ For instance in the USA, compared with others countries, the average longevity is not as high as the average richness, maybe also because of its not so healthy alimentary habit, or because of any other reasons too. However, its longevity is much higher than other poorer countries (even if in these countries the other variables, like climate, pollution, etc., are better).

${ }^{36}$ Methodology proposed in D'Acci L. (2009a, 2009b, 2008, 2007).
} 
Measuring only subjective well-being, we ignore the level of well-being objectively achieved. For example, if a person (A), who had got a really poor and difficult existence in the past, now has the same objective well-being as another person (B), who had a very rich and easy life, probably B will be unhappier than A, so his experienced utility can be lower than that of A. Imagine also to be able to quantify the objective well-being (like money and health) of a person on a scale from 1 to 10. If the objective well-being level of $A$ in the past was 1 , and today is 3 , and if B comes from a past of 10 and today is 7 , it is probable, following the theories shown in the previous paragraphs, that B proves to be unhappier than A. However, from an ethical point of view, it would be wrong to assign the same level of well-being to $\mathrm{A}$ and $\mathrm{B}^{37}$.

Therefore, we believe that both for ethical reasons and for empirical evidence ${ }^{38}$, objective well-being (like richness, especially under a certain level) should play an important part in the formation of a global indicator of well-being, but we also think that GDP on its own is not adequate to describe the well-being of a country, in the same way that richness on its own is not enough to describe the happiness of a person.

Following this direction, several alternative indicators were proposed in these last few years, like for example the Human Development Index (HDI) ${ }^{39}$, the Genuine Progress Indicator (GPI) ${ }^{40}$, the Index of Sustainable Economic Welfare (ISEW) ${ }^{41}$, the Gross National Happiness $(\mathrm{GNH})^{42}$, Quality of life index ${ }^{43}$, Life Quality Index $(\mathrm{LQI})^{44}$.

\footnotetext{
${ }^{37}$ For a deep contribution to the Ethic and Economy debate look at Sen (1987).

${ }^{38}$ Refer to Frey and Stutzer (2002), Paragraph 4, p. 108

39 The HDI combines normalized measures of life expectancy, literacy, educational attainment, and GDP per capita. Life expectancy at birth, as an index of population health and longevity; knowledge and education, as measured by the adult literacy rate (with two-thirds weighting) and the combined primary, secondary, and tertiary gross enrollment ratio (with one-third weighting). Standard of living, as measured by the natural logarithm (to reduce the impact beyond a certain level) of gross domestic product per capita at purchasing power parity (GDPppp). Each of these 3 factors has the same weight.

${ }^{40}$ The GPI indicator takes into account everything the GDP uses, but adding the cost of the negative effects related to economic activity (such as the cost of crime, cost of ozone depletion and cost of resource depletion, among others). Proposed in 1994 by Cliff Cobb.

${ }^{41}$ ISEW $=$ personal consumption + public non-defensive expenditures + capital formation + services from domestic labour - costs of environmental degradation - depreciation of natural capital - private defensive expenditures. The index is based on the ideas presented by William Nordhaus and James Tobin in their Measure of Economic Welfare (1972). It was first coined in 1989 by Herman Daly and John B. Cobb. They later went on to add several other "costs" to the definition of ISEW. In this later work they built the Genuine Progress Indicator.

${ }^{42}$ It includes Psychological wellbeing indicators, Ecology indicators, Health indicators, Education indicators, Culture indicators, Living Standards indicators, Time Use indicators, Community Vitality indicators and Good Governance indicators. It was coined in 1972 by Bhutan's former King Jigme Singye Wangchuck.

${ }^{43}$ The nine quality-of-life factors utilized and the indicators used to represent these factors are: Material wellbeing (GDP per person, at PPP in \$), Health (Life expectancy at birth (in years), Political stability and security, Family life (Divorce rate per 1,000 of population), converted into an index with a value of 1 (for the lowest divorce rates) to 5 (the highest), Community life (a dummy variable taking value 1 , if the country has either a high rate of church attendance or of trade-union membership, zero otherwise), Climate and geography (Latitude), Job security (Unemployment rate), Political freedom (The average indices of political and civil liberties. On a scale of 1 (completely free) to 7 (not free at all), Gender equality (Ratio of average male and female earnings). Developed by The Economist Intelligence Unit in 2005.

${ }^{44}$ The mathematical expression for the Life-Quality Index, L, is: $L=E^{K} G$ where $E$ is the expectancy of healthy life at birth, $G$ is the Gross Domestic Product (GDP) per person, and the
} 
The Well-being \& Progress Index (WIP), which we propose in this paper, combines measures of Health well-being, Economic well-being, Happiness, Human progress and Cultural progress.

Health well-being is represented by life expectancy at birth; Economic well-being is a combination between richness and equality, calculated using the GDP per capita, the Gini $^{45}$ index and the Unemployment total (as \% of labour force); Happiness is represented by Subjective well-being; Cultural-scientific progress is represented by an Education Index and the number of Researchers in research and development (per million people); Human progress is a combination between Freedom, Women's equality and Intentional homicides (per 100.000 people).

The Education Index is the same used in the Human Development Index (HDI), and it is measured by the adult literacy rate (with two-thirds weighting) and the combined primary, secondary, and tertiary gross enrollment ratio (with one-third weighting).

The Freedom index is a combination between Political rights (Electoral process, Political pluralism and participation, and the Functioning of government), and Civil liberties (Freedom of expression and belief, Associational and organizational rights, Rule of law, Personal autonomy and Individual rights) ${ }^{46}$.

Women's equality combines the Seats in parliament held by women, the Ratio of estimated female to male earned income and the Combined gross enrolment ratio for primary, secondary and tertiary education, female (\%).

Each measure ${ }^{47}$ is transformed as an index from 0 to 1 through this passage: index $=\left(x-x_{\min }\right) /\left(x_{\max }-x_{\min }\right)$, where $x$ is the value that we want to transform and $x$ min and $x \max$ are the minimum and the maximum values shown.

parameter $K$ is a constant based on time budget studies which are available for many countries $(K$ is approximately equal to 5.0 for developed nations). Defined by Nathwani in 1997.

${ }^{45}$ It is a coefficient which measures the equality of income distribution, where value 0 represents absolute equality, and value 100 indicates absolute inequality.

46 "The rating process is based on a checklist of 10 politically correct questions and 15 civil liberty questions. The politically correct questions are grouped into three subcategories: Electoral Process (3 questions), Political Pluralism and Participation (4), and the Functioning of Government (3). The civil liberty questions are grouped into four subcategories: Freedom of Expression and Belief (4 questions), Associational and Organizational Rights (3), Rule of Law (4), and Personal Autonomy and Individual Rights (4)". (from www. freedomhouse.org)

${ }^{47}$ Life expectancy at birth, GDP per capita, Gini index, Unemployment total, Education Index, Researchers in research and development, Women's equality and Intentional homicides are calculated on the data set of the Human Development Report 2007/2008 and of the UNESCO Institute for Statistics 2007; Freedom is calculated on a data set and survey of Freedomhouse; Subjective Well-being comes from Marks, N., Abdallah, S., Simms, A, Thompson, S. (2006), The Happy Planet Index, New Economics Foundation, London. 


\begin{tabular}{|c|c|c|c|c|c|c|c|c|c|c|}
\hline \multirow[b]{2}{*}{ countries } & \multirow{2}{*}{$\begin{array}{l}\text { HEALTH } \\
\text { Life expectancy } \\
\text { at birth }\end{array}$} & \multirow{2}{*}{$\begin{array}{c}\text { HAPPINESS } \\
\text { SWB }\end{array}$} & \multicolumn{3}{|c|}{ ECONOMIC WELL-BEING } & \multicolumn{2}{|c|}{$\begin{array}{l}\text { CUTLURAL } \\
\text { SCIENTIFIC } \\
\text { PROGRESS }\end{array}$} & \multicolumn{3}{|c|}{ HUMAN PROGRESS } \\
\hline & & & $\begin{array}{l}\text { GDP per } \\
\text { capita } \\
\text { (PPP USS) }\end{array}$ & gini index & $\begin{array}{c}\text { Unemployment } \\
\text { total } \\
\text { (\%of labour force) }\end{array}$ & $\begin{array}{l}\text { Education } \\
\text { index }\end{array}$ & $\begin{array}{l}\text { Researchers } \\
\text { in R\&D } \\
\text { (per million } \\
\text { people) }\end{array}$ & Freedom & Woman equality & $\begin{array}{l}\text { Intentional } \\
\text { homicides } \\
\text { (per 100000people) }\end{array}$ \\
\hline Argentina & 0,821 & 0,646 & 0,225 & 0,249 & 0,738 & 0,903 & 0,078 & 0,818 & 0,672 & \\
\hline Australia & 0,967 & 0,769 & 0,521 & 0,703 & 0,895 & 1,000 & 0,472 & 1,000 & 0,802 & 0,986 \\
\hline Austria & 0,931 & 0,900 & 0,553 & 0,876 & 0,898 & 0,943 & 0,369 & 1,000 & 0,582 & 0,994 \\
\hline Belgium & 0,916 & 0,769 & 0,526 & 0,766 & 0,804 & 0,966 & 0,382 & 1,000 & 0,685 & 0,982 \\
\hline Bolivia & 0,579 & 0,308 & 0,032 & 0,000 & 0,878 & 0,731 & 0,000 & 0,636 & 0,469 & 0,961 \\
\hline Brazil & 0,746 & 0,515 & 0,126 & 0,088 & 0,785 & 0,768 & 0,029 & 0,818 & 0,463 & \\
\hline Bulgaria & 0,770 & 0,000 & 0,137 & 0,873 & 0,751 & 0,859 & 0,148 & 0,909 & 0,550 & 0,957 \\
\hline Canada & 0,952 & 0,846 & 0,547 & 0,777 & 0,856 & 0,996 & & 1,000 & 0,212 & 0,976 \\
\hline China & 0,766 & 0,515 & 0,098 & 0,373 & 0,914 & 0,672 & 0,042 & 0,000 & 0,454 & 0,973 \\
\hline Colombia & 0,761 & 0,746 & 0,108 & 0,042 & 0,704 & 0,739 & 0,076 & 0,636 & 0,271 & 0,000 \\
\hline Croatia & 0,833 & 0,415 & 0,204 & 0,879 & 0,680 & 0,802 & 0,153 & 0,818 & 0,515 & 0,978 \\
\hline Denmark & 0,895 & 1,000 & 0,557 & 1,000 & 0,923 & 1,000 & 0,635 & 1,000 & 0,520 & 0,994 \\
\hline Ecuador & 0,818 & 0,338 & 0,058 & 0,184 & 0,812 & 0,716 & 0,049 & 0,636 & 0,073 & 0,713 \\
\hline Egypt & 0,722 & 0,131 & 0,058 & 0,726 & 0,727 & 0,451 & 0,048 & 0,182 & 0,348 & 1,000 \\
\hline ElSalvador & 0,737 & 0,592 & 0,073 & 0,218 & 0,843 & 0,535 & 0,046 & 0,727 & 0,345 & 0,501 \\
\hline Estonia & 0,734 & 0,208 & 0,245 & 0,686 & 0,812 & 0,947 & 0,312 & 1,000 & 0,617 & 0,897 \\
\hline Finland & 0,919 & 0,877 & 0,527 & 0,938 & 0,818 & 1,000 & 1,000 & 1,000 & 0,615 & 0,961 \\
\hline France & 0,950 & 0,592 & 0,497 & 0,774 & 0,771 & 0,977 & 0,401 & 1,000 & 0,545 & 0,981 \\
\hline Germany & 0,923 & 0,746 & 0,481 & 0,898 & 0,798 & 0,916 & 0,407 & 1,000 & 0,531 & 0,990 \\
\hline Greece & 0,919 & 0,515 & 0,379 & 0,729 & 0,785 & 0,952 & 0,168 & 0,909 & 0,701 & 0,994 \\
\hline Iceland & 0,981 & 0,900 & 0,600 & 1,000 & 0,948 & 0,968 & 0,867 & 1,000 & 0,386 & 0,990 \\
\hline India & 0,555 & 0,285 & 0,043 & 0,658 & 0,912 & 0,215 & 0,000 & 0,727 & 0,257 & 0,947 \\
\hline Indonesia & 0,699 & 0,592 & 0,049 & 0,729 & 0,779 & 0,657 & 0,011 & 0,727 & 0,205 & 0,989 \\
\hline Iran & 0,711 & 0,438 & 0,119 & 0,483 & 0,713 & 0,577 & 0,150 & 0,091 & 0,385 & 0,960 \\
\hline Ireland & 0,907 & 0,846 & 0,634 & 0,729 & 0,909 & 1,000 & 0,331 & 1,000 & 0,606 & 0,992 \\
\hline Italy & 0,952 & 0,669 & 0,465 & 0,681 & 0,843 & 0,926 & 0,142 & 1,000 & 0,506 & 0,987 \\
\hline Japan & 1,000 & 0,492 & 0,512 & 0,994 & 0,917 & 0,901 & 0,670 & 0,909 & 0,290 & 0,998 \\
\hline Kazakhstan & 0,608 & 0,385 & 0,117 & 0,740 & 0,798 & 0,958 & 0,066 & 0,182 & 0,622 & 0,737 \\
\hline Kuwait & 0,880 & 0,746 & 0,428 & & 1,000 & 0,743 & & 0,455 & 0,340 & 0,990 \\
\hline Latvia & 0,754 & 0,108 & 0,215 & 0,633 & 0,790 & 0,933 & 0,170 & 0,909 & 0,332 & 0,868 \\
\hline Lithuania & 0,766 & 0,108 & 0,229 & 0,681 & 0,801 & 0,941 & 0,262 & 1,000 & 0,573 & 0,856 \\
\hline Luxembourg & 0,907 & 0,846 & 1,000 & & 0,939 & 0,893 & 0,542 & 1,000 & 0,529 & 0,992 \\
\hline Macedonia & 0,797 & 0,154 & 0,106 & 0,596 & 0,000 & 0,752 & 0,050 & 0,636 & 0,420 & 0,970 \\
\hline Madagascar & 0,428 & 0,385 & 0,000 & 0,356 & 0,906 & 0,320 & 0,004 & 0,545 & 0,403 & 0,998 \\
\hline Malaysia & 0,794 & 0,800 & 0,168 & 0,308 & 0,931 & 0,676 & 0,023 & 0,455 & 0,375 & 0,968 \\
\hline Mauritius & 0,763 & 0,569 & 0,199 & & 0,765 & 0,621 & 0,031 & 0,909 & 0,377 & 0,966 \\
\hline Mexico & 0,840 & 0,669 & 0,166 & 0,395 & 0,942 & 0,726 & 0,019 & 0,727 & 0,510 & 0,798 \\
\hline Nepal & 0,529 & 0,308 & 0,011 & 0,364 & 0,981 & 0,000 & 0,061 & 0,364 & 0,499 & 0,952 \\
\hline Netherlands & 0,926 & 0,823 & 0,536 & 0,825 & 0,923 & 0,989 & 0,306 & 1,000 & 0,743 & 0,990 \\
\hline New Zeland & 0,940 & 0,800 & 0,406 & 0,675 & 0,925 & 1,000 & 0,496 & 1,000 & 0,537 & 0,986 \\
\hline Nicaragua & 0,751 & 0,515 & 0,046 & 0,480 & 0,693 & 0,482 & 0,079 & 0,636 & 0,388 & 0,801 \\
\hline Norway & 0,940 & 0,800 & 0,683 & 0,969 & 0,934 & 0,996 & 0,579 & 1,000 & 0,325 & 0,994 \\
\hline Panama & 0,828 & 0,746 & 0,113 & 0,113 & 0,746 & 0,758 & 0,110 & 0,909 & 0,441 & 0,852 \\
\hline Paraguay & 0,737 & 0,569 & 0,063 & 0,048 & 0,807 & 0,705 & 0,087 & 0,636 & 0,490 & 0,804 \\
\hline Peru & 0,722 & 0,338 & 0,086 & 0,229 & 0,715 & 0,745 & 0,014 & 0,727 & 0,562 & 0,918 \\
\hline Philippines & 0,730 & 0,538 & 0,071 & 0,441 & 0,826 & 0,779 & 0,047 & 0,545 & 0,513 & 0,937 \\
\hline Poland & 0,830 & 0,415 & 0,218 & 0,723 & 0,649 & 0,912 & 0,190 & 1,000 & 0,567 & 0,981 \\
\hline Portugal & 0,890 & 0,462 & 0,329 & 0,610 & 0,818 & 0,857 & 0,237 & 1,000 & 0,239 & 0,978 \\
\hline Qatar & 0,825 & 0,692 & 0,451 & & 0,923 & 0,703 & & 0,182 & 0,509 & 0,994 \\
\hline Romania & 0,751 & 0,231 & 0,137 & 0,822 & 0,831 & 0,815 & 0,111 & 0,818 & 0,419 & 0,968 \\
\hline Russian & 0,586 & 0,000 & 0,167 & 0,571 & 0,815 & 0,922 & 0,415 & 0,182 & 0,833 & 0,687 \\
\hline SaudiArabia & 0,758 & 0,769 & 0,249 & & 0,887 & 0,606 & & 0,000 & 0,444 & \\
\hline Singapore & 0,931 & 0,669 & 0,485 & 0,497 & 0,884 & 0,821 & 0,633 & 0,364 & 0,518 & 0,998 \\
\hline Slovakia & 0,806 & 0,285 & 0,252 & 0,969 & 0,660 & 0,848 & 0,242 & 1,000 & 0,440 & 0,970 \\
\hline South Africa & 0,246 & 0,362 & 0,172 & 0,065 & 0,296 & 0,606 & 0,024 & 0,818 & 0,512 & 0,244 \\
\hline Spain & 0,957 & 0,692 & 0,443 & 0,718 & 0,796 & 0,987 & 0,269 & 1,000 & 0,409 & 0,987 \\
\hline Srilanka & 0,744 & 0,462 & 0,062 & 0,562 & 0,818 & 0,623 & 0,001 & 0,455 & 0,352 & 0,899 \\
\hline Sweden & 0,957 & 0,877 & 0,533 & 0,992 & 0,837 & 0,968 & 0,687 & 1,000 & 0,418 & 0,968 \\
\hline Switzerland & 0,976 & 1,000 & 0,585 & 0,746 & 0,920 & 0,901 & 0,451 & 1,000 & 0,501 & 0,960 \\
\hline Tajikistan & 0,617 & 0,462 & 0,007 & 0,777 & 0,956 & 0,796 & 0,070 & 0,182 & 0,361 & 0,884 \\
\hline Tunisia & 0,789 & 0,538 & 0,126 & 0,573 & 0,638 & 0,488 & 0,116 & 0,091 & 0,622 & 0,987 \\
\hline Turkey & 0,739 & 0,262 & 0,126 & 0,466 & 0,757 & 0,619 & 0,029 & 0,636 & 0,306 & 0,945 \\
\hline United Kingdom & 0,921 & 0,723 & 0,545 & 0,681 & 0,967 & 0,952 & & 1,000 & 0,689 & 0,973 \\
\hline UnitedArabEmirates & 0,904 & & 0,415 & & 0,884 & 0,575 & 0,335 & 0,182 & 0,426 & 0,997 \\
\hline Uruguay & 0,847 & 0,515 & 0,152 & 0,429 & 0,693 & 0,893 & 0,032 & 1,000 & 0,558 & 0,917 \\
\hline USA & 0,895 & 0,800 & 0,691 & 0,545 & 0,903 & 0,954 & 0,582 & 1,000 & 0,524 & 0,917 \\
\hline Zambia & 0,000 & 0,154 & 0.002 & 0.263 & 0.699 & 0.288 & 0.051 & 0,545 & 0,033 & 0,876 \\
\hline
\end{tabular}

Fig. 5 Indices used for calculated WIP

The Well-being \& Progress Index is the medium value of these 10 indices in which each one has the same influence, except for Researchers in research and development that values half.

Figures 5 and 6 show the final rank of WIP in some countries and a comparison among WIP, GDP, GDP per capita, HDI and the Quality-of-life index. 


\begin{tabular}{|c|c|c|c|c|c|c|c|c|c|}
\hline \multicolumn{2}{|c|}{ GDP $_{(\mathrm{PPP})}$} & \multicolumn{2}{|c|}{ GDP per capita } & \multicolumn{2}{|c|}{$\begin{array}{c}\text { Well-Being \& } \\
\text { Progress Index } \\
\text { WIP }\end{array}$} & \multicolumn{2}{|c|}{$\begin{array}{c}\text { Human Development } \\
\text { Index HDI }\end{array}$} & \multicolumn{2}{|c|}{ Quality-of-life index } \\
\hline USA & 1,000 & Luxembourg & 1,000 & Iceland & 0,760 & Luxembourg & 0,933 & Ireland & 8,333 \\
\hline China & 0,710 & USA & 0,691 & Denmark & 0,759 & Norway & 0,873 & Switzerland & 8,068 \\
\hline Japan & 0,321 & Norway & 0,683 & Finland & 0,757 & Iceland & 0,850 & Norway & 8,051 \\
\hline India & 0,304 & Ireland & 0,634 & Norway & 0,730 & Ireland & 0,847 & Luxembourg & 8,015 \\
\hline Germany & 0,195 & Iceland & 0,600 & Sweden & 0,729 & USA & 0,846 & Sweden & 7,937 \\
\hline United Kingdom & 0,161 & Switzerland & 0,585 & Netherlands & 0,728 & Canada & 0,832 & Australia & 7,925 \\
\hline France & 0,148 & Denmark & 0,557 & Australia & 0,726 & Australia & 0,829 & Iceland & 7,911 \\
\hline Italy & 0,134 & Austria & 0,553 & Austria & 0,723 & Switzerland & 0,821 & Italy & 7,810 \\
\hline Brazil & 0,126 & Canada & 0,547 & Switzerland & 0,722 & Sweden & 0,819 & Denmark & 7,796 \\
\hline Russian & 0,124 & United Kingdom & 0,545 & Ireland & 0,715 & Denmark & 0,817 & Spain & 7,727 \\
\hline Spain & 0,094 & Netherlands & 0,536 & Belgium & 0,697 & Netherlands & 0,817 & Singapore & 7,719 \\
\hline Mexico & 0,089 & Sweden & 0,533 & USA & 0,695 & Finland & 0,815 & Finland & 7,618 \\
\hline Canada & 0,086 & Finland & 0,527 & New Zeland & 0,688 & Austria & 0,809 & USA & 7,615 \\
\hline Indonesia & 0,068 & Belgium & 0,526 & Germany & 0,684 & France & 0,808 & Canada & 7,599 \\
\hline Australia & 0,051 & Australia & 0,521 & United Kingdom & 0,682 & United Kingdom & 0,806 & New Zeland & 7,436 \\
\hline Turkey & 0,048 & Japan & 0,512 & Luxembourg & 0,672 & Japan & 0,804 & Netherlands & 7,433 \\
\hline Argentina & 0,044 & France & 0,497 & Japan & 0,668 & Belgium & 0,803 & Japan & 7,392 \\
\hline Iran & 0,043 & Singapore & 0.485 & France & 0,664 & Spain & 0,796 & Portugal & 7,307 \\
\hline Netherlands & 0,042 & Germany & 0,481 & Canada & 0,651 & New Zeland & 0,782 & Austria & 7,268 \\
\hline Poland & 0,042 & Italy & 0,465 & Spain & 0,646 & Italy & 0,781 & Greece & 7,163 \\
\hline South Africa & 0,041 & Qatar & 0,451 & Italy & 0,644 & Germany & 0,773 & Belgium & 7,095 \\
\hline Philippines & 0,034 & Spain & 0,443 & Greece & 0,629 & Greece & 0,750 & France & 7,084 \\
\hline SaudiArabia & 0,029 & Kuwait & 0,428 & Singapore & 0,577 & Singapore & 0,745 & Germany & 7,048 \\
\hline Belgium & 0,026 & UnitedArabEmirates & 0,415 & Poland & 0,569 & Portugal & 0,692 & United Kingdom & 6,917 \\
\hline Colombia & 0,026 & New Zeland & 0,406 & Estonia & 0,569 & Kuwait & 0,684 & Mexico & 6,766 \\
\hline Egypt & 0,025 & Greece & 0,379 & Slovakia & 0,566 & Qatar & 0,660 & Malaysia & 6,608 \\
\hline Sweden & 0,023 & Portugal & 0,329 & Portugal & 0,560 & Poland & 0,653 & Brazil & 6,470 \\
\hline Austria & 0,022 & Slovakia & 0,252 & Lithuania & 0,550 & Argentina & 0,650 & Argentina & 6,469 \\
\hline Malaysia & 0,022 & SaudiArabia & 0,249 & Croatia & 0,550 & Lithuania & 0,645 & Qatar & 6,462 \\
\hline Switzerland & 0,021 & Estonia & 0,245 & Argentina & 0,538 & Estonia & 0,642 & Srilanka & 6,417 \\
\hline Greece & 0,020 & Lithuania & 0,229 & Uruguay & 0,537 & Slovakia & 0,636 & Philippines & 6,403 \\
\hline Portugal & 0,017 & Argentina & 0,225 & Mexico & 0,525 & Latvia & 0,634 & Slovakia & 6,381 \\
\hline Romania & 0,015 & Poland & 0,218 & Bulgaria & 0,518 & UnitedArabEmirates & 0,631 & Uruguay & 6,368 \\
\hline Norway & 0,015 & Latvia & 0,215 & Romania & 0,514 & Uruguay & 0,631 & Panama & 6,361 \\
\hline Denmark & 0,014 & Croatia & 0,204 & Latvia & 0,501 & Croatia & 0,613 & Poland & 6,309 \\
\hline Peru & 0,013 & Mauritius & 0,199 & Panama & 0,496 & Bulgaria & 0,589 & Croatia & 6,301 \\
\hline Finland & 0,013 & South Africa & 0,172 & Kuwait & 0,483 & Mexico & 0,577 & Turkey & 6,286 \\
\hline Ireland & 0,012 & Malaysia & 0,168 & Malaysia & 0,476 & Romania & 0,568 & Ecuador & 6,272 \\
\hline Singapore & 0,010 & Russian & 0,167 & Philippines & 0,470 & Panama & 0,566 & Peru & 6,216 \\
\hline Kazakhstan & 0,009 & Mexico & 0,166 & Indonesia & 0,468 & Kazakhstan & 0,561 & Colombia & 6,176 \\
\hline New Zeland & 0,008 & Uruguay & 0,152 & Kazakhstan & 0,468 & Russian & 0,559 & Kuwait & 6,171 \\
\hline SriLanka & 0,007 & Romania & 0,137 & Brazil & 0,455 & Macedonia & 0,551 & EISalvador & 6,164 \\
\hline Slovakia & 0,006 & Bulgaria & 0,137 & Qatar & 0,451 & Brazil & 0,547 & Bulgaria & 6,162 \\
\hline Tunisia & 0,006 & Turkey & 0,126 & Russian & 0,451 & Malaysia & 0,546 & Romania & 6,105 \\
\hline Bulgaria & 0,005 & Brazil & 0,126 & Mauritius & 0,444 & SaudiArabia & 0,538 & China & 6,083 \\
\hline Kuwait & 0,005 & Tunisia & 0,126 & Tajikistan & 0,441 & Colombia & 0,536 & Lithuania & 6,033 \\
\hline Croatia & 0,004 & Iran & 0,119 & Peru & 0,435 & Ecuador & 0,531 & Latvia & 6,008 \\
\hline Ecuador & 0,004 & Kazakhstan & 0,117 & Paraguay & 0,431 & Mauritius & 0,528 & Estonia & 5,905 \\
\hline Lithuania & 0,003 & Panama & 0,113 & EISalvador & 0,431 & Philippines & 0,527 & UnitedArabEmirates & 5,899 \\
\hline Nepal & 0,003 & Colombia & 0,108 & SriLanka & 0,429 & Peru & 0,518 & Indonesia & 5,814 \\
\hline EISalvador & 0,002 & Macedonia & 0,106 & Colombia & 0,426 & China & 0,512 & SaudiArabia & 5,767 \\
\hline Uruguay & 0,002 & China & 0,098 & Nicaragua & 0,424 & Paraguay & 0,502 & India & 5,759 \\
\hline Latvia & 0,002 & Peru & 0,086 & Turkey & 0,413 & Turkey & 0,495 & Paraguay & 5,756 \\
\hline Luxembourg & 0,002 & ElSalvador & 0,073 & Tunisia & 0,413 & SriLanka & 0,476 & Nicaragua & 5,663 \\
\hline Paraguay & 0,001 & Philippines & 0,071 & China & 0,401 & Tajikistan & 0,473 & Egypt & 5,605 \\
\hline Bolivia & 0,001 & Paraguay & 0,063 & SaudiArabia & 0,391 & Iran & 0,469 & Bolivia & 5,492 \\
\hline Panama & 0,001 & SriLanka & 0,062 & Ecuador & 0,385 & Indonesia & 0,468 & Tunisia & 5,472 \\
\hline Estonia & 0,001 & Ecuador & 0,058 & India & 0,384 & Tunisia & 0,468 & Iran & 5,343 \\
\hline Nicaragua & 0,001 & Egypt & 0,058 & Bolivia & 0,382 & EISalvador & 0,448 & Macedonia & 5,337 \\
\hline Madagascar & 0,001 & Indonesia & 0,049 & Iran & 0,378 & Bolivia & 0,447 & SouthAfrica & 5,245 \\
\hline Mauritius & 0,001 & Nicaragua & 0,046 & UnitedArabEmirates & 0,374 & Nicaragua & 0,427 & Kazakhstan & 5,082 \\
\hline Macedonia & 0,000 & India & 0,043 & Macedonia & 0,367 & Egypt & 0,410 & Russia & 4,796 \\
\hline Zambia & 0,000 & Bolivia & 0,032 & Egypt & 0,355 & South Africa & 0,342 & Tajikistan & 4,754 \\
\hline Iceland & 0,000 & Nepal & 0,011 & Madagascar & 0,352 & India & 0,271 & & \\
\hline \multirow[t]{3}{*}{ Tajikistan } & 0,000 & Tajikistan & 0,007 & South Africa & 0,325 & Madagascar & 0,249 & & \\
\hline & & Zambia & 0,002 & Nepal & 0,325 & Nepal & 0,180 & & \\
\hline & & Madagascar & 0,000 & Zambia & 0,211 & imbia & 77 & & \\
\hline
\end{tabular}

Fig. 6 Comparison among WIP and GDP, GDP per capita, HDI and Quality-of-life index.

The Well-being \& Progress Index also includes an additional index: the Environmental well-being, measured by two indicators: Quality of the Urban Environment and Ecological behaviours. However, the data set, utilized in this paper, does not include information from enough countries, so it will not be considered (D'Acci and Lombardi 2010).

Fig. 6 and 7 provides evidence in black of the first 10 richest countries, in the world (respectively for GDP and GDP per capita), allowing you to follow how their ranks change when we use other indices. 


\begin{tabular}{|c|c|c|c|c|c|c|c|}
\hline \multicolumn{2}{|c|}{ GDP per capita } & \multicolumn{2}{|c|}{$\begin{array}{c}\text { Well-Being } \& \\
\text { Progress Index } \\
\text { WIP }\end{array}$} & \multicolumn{2}{|c|}{$\begin{array}{l}\text { Human Development } \\
\text { Index HDI }\end{array}$} & \multicolumn{2}{|c|}{ Quality-of-life index } \\
\hline Luxembourg & 1,000 & Iceland & 0,760 & Luxembourg & 0,933 & Ireland & 8,333 \\
\hline USA & 0,691 & Denmark & 0,759 & Norway & 0,873 & Switzerland & 8,068 \\
\hline Norway & 0,683 & Finland & 0,757 & Iceland & 0,850 & Norway & 8,051 \\
\hline Ireland & 0,634 & Norway & 0,730 & Ireland & 0,847 & Luxembourg & 8,015 \\
\hline Iceland & 0,600 & Sweden & 0,729 & USA & 0,846 & Sweden & 7,937 \\
\hline Switzerland & 0,585 & Netherlands & 0,728 & Canada & 0,832 & Australia & 7,925 \\
\hline Denmark & 0,557 & Australia & 0,726 & Australia & 0,829 & Iceland & 7,911 \\
\hline Austria & 0,553 & Austria & 0,723 & Switzerland & 0,821 & Italy & 7,810 \\
\hline Canada & 0,547 & Switzerland & 0,722 & Sweden & 0,819 & Denmark & 7,796 \\
\hline United Kingdom & 0,545 & Ireland & 0,715 & Denmark & 0,817 & Spain & 7,727 \\
\hline Netherlands & 0,536 & Belgium & 0,697 & Netherlands & 0,817 & Singapore & 7,719 \\
\hline Sweden & 0,533 & USA & 0,695 & Finland & 0,815 & Finland & 7,618 \\
\hline Finland & 0,527 & New Zeland & 0,688 & Austria & 0,809 & USA & 7,615 \\
\hline Belgium & 0,526 & Germany & 0,684 & France & 0,808 & Canada & 7,599 \\
\hline Australia & 0,521 & United Kingdom & 0,682 & United Kingdom & 0,806 & New Zeland & 7,436 \\
\hline Japan & 0,512 & Luxembourg & 0,672 & Japan & 0,804 & Netherlands & 7,433 \\
\hline France & 0,497 & Japan & 0,668 & Belgium & 0,803 & Japan & 7,392 \\
\hline Singapore & 0,485 & France & 0,664 & Spain & 0,796 & Portugal & 7,307 \\
\hline Germany & 0,481 & Canada & 0,651 & New Zeland & 0,782 & Austria & 7,268 \\
\hline Italy & 0,465 & Spain & 0,646 & Italy & 0,781 & Greece & 7,163 \\
\hline Qatar & 0,451 & Italy & 0,644 & Germany & 0,773 & Belgium & 7,095 \\
\hline Spain & 0,443 & Greece & 0,629 & Greece & 0,750 & France & 7,084 \\
\hline Kuwait & 0,428 & Singapore & 0,577 & Singapore & 0,745 & Germany & 7,048 \\
\hline UnitedArabEmirates & 0,415 & Poland & 0,569 & Portugal & 0,692 & United Kingdom & 6,917 \\
\hline
\end{tabular}

Fig. 7 Comparison among WIP and GDP per capita, HDI and the Quality-of-life index.

Fig. 8 illustrates the importance of using a more holistic index to measure the global Well-being and progress of a country.

The vertical lines provide evidence on how countries with similar richness per capita have very large differences in the Well-being \& Progress Index. For example Arab Emirates and New Zeland have almost the same value of GDP per capita index (respectively 0,415 and 0,406$)$ but a very different WIP $(0,374$ and 0,688 ); also Italy and Qatar (respectively 0,465 and 0,451 as GDP per capita, but 0,644 and 0,451 as WIP).

The horizontal lines show evidence of how a country can show the same level of Well-being \& Progress Index even with less richness per capita.

One piece of evidence derived from this chart (Fig. 8), is that richer does not always mean a higher level of wellbeing and progress.

These kinds of comparisons are more clear and correct if we calculate WIP without GDP per capita and Health (we do not include Health, meaning longevity, because it is strongly connected with richness in a logarithmic way, Fig. 4), and we call this new index WIP*. WIP* measures the following indices: Human rights (included in the previous Freedom index), equality (by GINI index), Unemployment, Education, Research, Women's condition, Intentional homicides and Subjective Well-being (Fig. 9). 


\section{COMPARISON AMONG COUNTRIES WITH CLOSE RICHNESS \\ BUT DISTANT WIP, AND VICE VERSA}

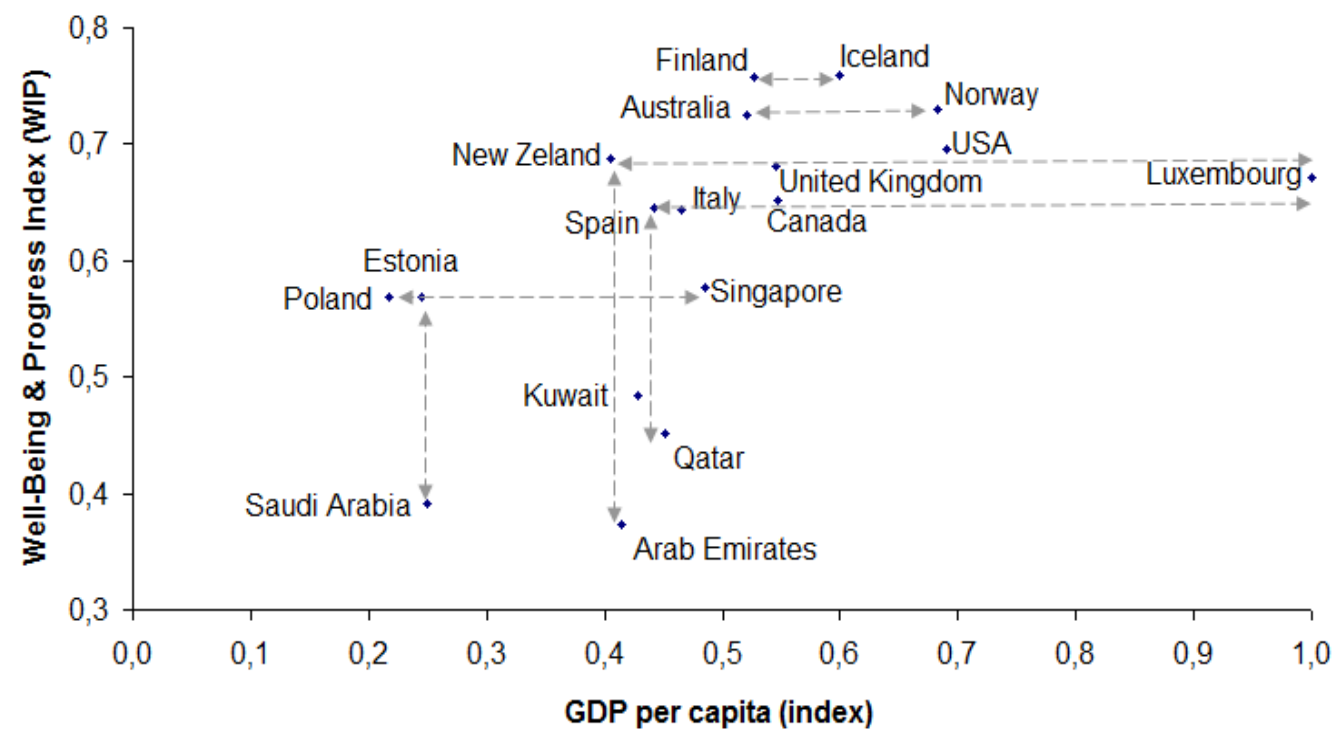

Fig. 8 Comparison among countries with similar values of GDP per capita but with a distant Wellbeing \& Progress Index, and vice versa
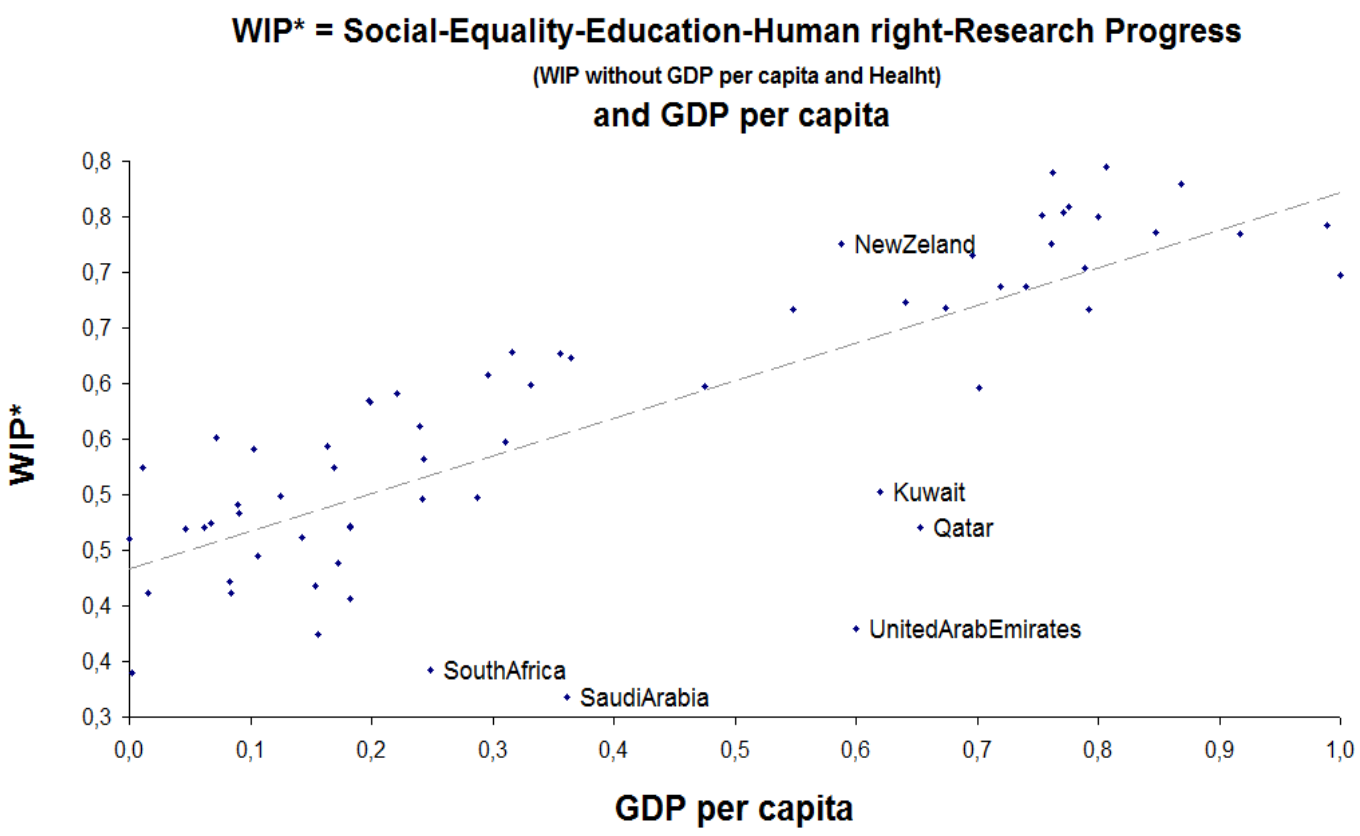

Fig. 9 Comparison between GDP per capita and WIP*

Looking at the all of the samples (66 countries) used in this research (Fig. $9^{48}$ ), the relation between GDP per capita and WIP* is clear, which shows how, on average, the richer a country is, the higher its social/cultural level (WIP*) is... or,

${ }^{48}$ In this figure Luxembourg does not appear. 
maybe, vice versa. This is the crucial point: a country improves its WIP* thanks to its richness, or a country improves its richness thanks to its WIP*? ${ }^{49}$

Fig. 10 shows some other comparisons among expressed Happiness, GDP per capita, Freedom, Longevity and Illiteracy.

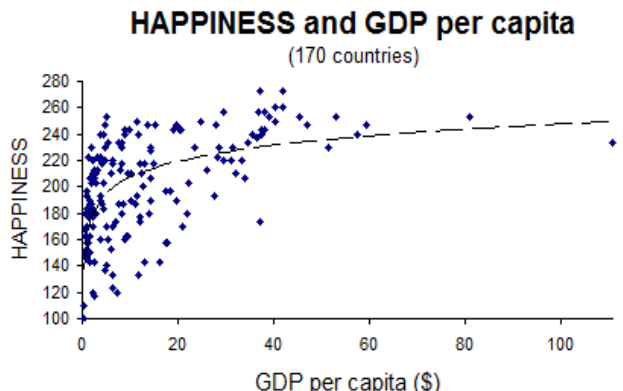

GDP per capita and FREEDOM

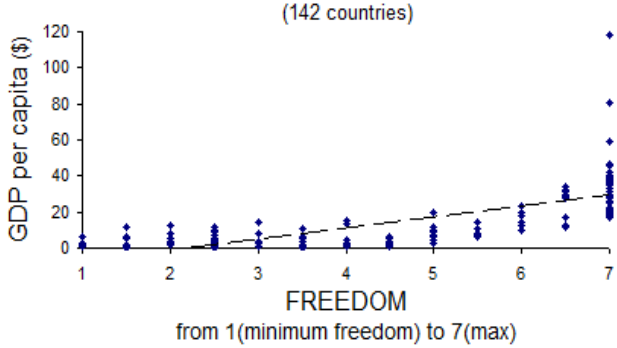

ILLITERACY and FREEDOM

(147 countries)

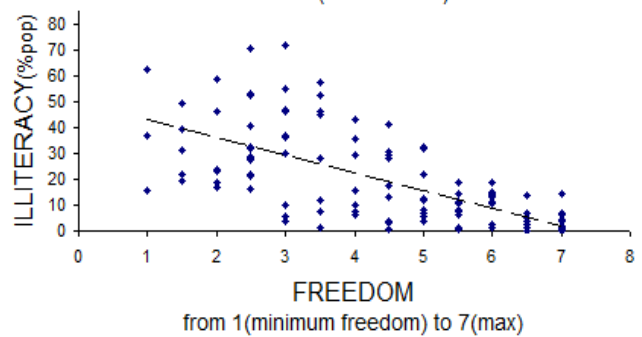

HAPPINESS and FREEDOM

(161 countries)

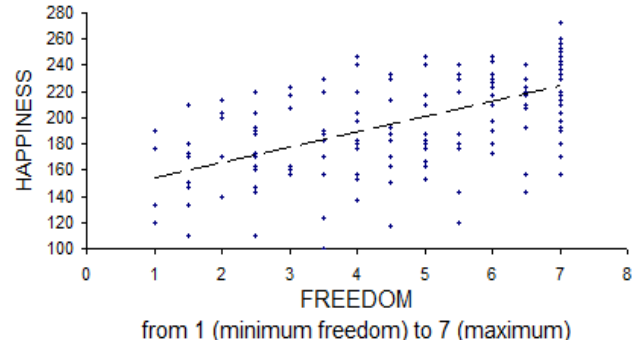

LONGEVITY and FREEDOM

(144 countries)

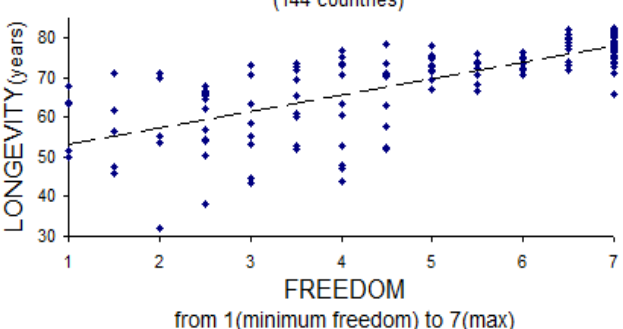

ILLITERACY and HAPPINESS

(117 countries)

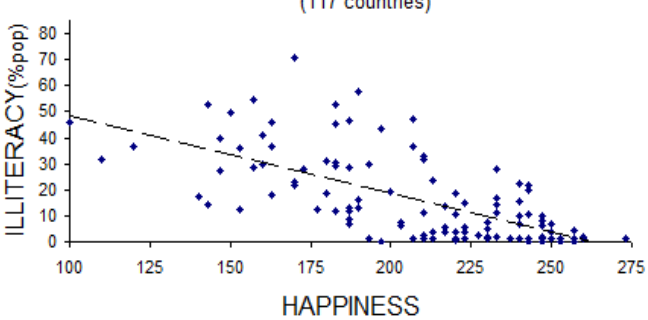

Fig. 10 Elaboration from the follow data: Happiness (Marks N., Abdallah S., Simms A, Thompson S. (2006), The Happy Planet Index, London: New Economics Foundation); GDP per capita 2009, Longevity 2009, (Central Intelligence Agency); Freedom 2009 (www.freedomhouse.org); Illiteracy (UNESCO).

\section{Conclusion}

History shows how humanity development has sometimes momentarily decreased in certain aspects during periods of time, lasting from a few decades to a few centuries; we can refer to them as Negative Transitory Cycles (NTC). However, when we look at the same history in a larger temporal perspective, we can see that, on average, our life has improved, both in quality and duration; we call this Net Positive Development (NPD) ${ }^{50}$.

\footnotetext{
${ }^{49}$ This is a good question, but we like to point out that both, GDP and WIP*, may also improve independently or because they are driven by some other unobserved factor.

${ }^{50}$ Although various aspects of people's lives have improved over history, they do not seem to have improved overall. It depends on the point of view, for example if we consider the risks to us and future generations from factors such as climate change and environmental degradation which may
} 
The desire to progress is part of human nature; it is an inevitable, automatic process that we should drive forward in the cleverest way, attenuating, as much as possible, future Negative Transitory Cycles and heightening Net Positive Development.

Looking back at past improvements and believing in human intelligence, we like to think that our development will drive us toward a greater level of well-being and progress, which must include richness, but also ethics, civilly, environment, education, science, equality, and human rights.

This paper has shown the correlation among these factors. In fact it was aiming to be both a theoretical and empirical discussion about how important it is to think of the concepts of wellbeing and progress in a more holistic way.

\section{References}

Allen R.G.D., Hicks J.R. (1934), “A Reconsideration of the Theory of Value, I”, Economica, 1, pp. $52-75$.

Arrigo U., Sordelli M., "Alcuni aspetti problematici nel dibattito su "Happiness and Economics", XVI Conference of "Società Italiana di Economica Pubblica", Pavia, 7-8/11/2004.

Bentham J., (1789), An Introduction to the Principles of Morals and Legislation, Oxford, Basil Blakwell, 1960

Becker G.S., “A theory of Social Interactions”, Journal of Political Economy, 82(6), 1974, pp. 1063-1093.

Edgeworth F.Y., Mathematical Psychics: An Essay on the Application of Mathematics to the Moral Sciences, Kegan Paul, London, 1881, reprinted Kelly M., New York 1967.

Bernoulli D., "Exposition of a New Theory on the Measurement of Risk", in Econometrica, 22(1), 1954, pp. 23-36.

Blanchflower D.G., Oswald A.J., "Well-Being over Time in Britain and the USA", NBER Working Paper n. 7487, National Bureau of Economic Research, 2000, Cambridge (Mass.)

Brickman P., Cambell D.T., "Hedonic Relativism and Planning the Good Society", in Appely M.H. (eds), Adaptation Level Theory: A Symposium, Academic Press, New York, 1971.

Carrol C.D., Weil D.N., "Saving and Growth: A reinterpretation", Carnegie-Rochester Conference Series ono Public Policy, 40(0), 1994, pp. 133-192.

D'Acci L., Zorzi F., "Un modello per la simulazione dei valori immobiliari”, in Sistemi economici locali e mercati immobiliari, E. Mollica, Gangemi, 2007.

D'Acci L. (2008), Grown, urban transformation, real estate value: econometric cellular automata for the simulation of positional value, in Lecture Notes in Computer Science, LNCS 5072, Springer-Verlag, Berlin.

D’Acci L. (2009a), Spatial Distribution of Social Benefit Given by Urban Attractions: a Test of UrAD Model, in Lecture Notes in Computer Science LNCS 5592, pp. 237-252, Springer-Verlag Berlin Heidelberg.

D’Acci L. (2009b), A mathematical aid for efficient distribution of social benefit in urban planning, in Scarlatti F., Rabino G., (editors), Advances in Models and Methods for Planning, Pitagora, Bologna.

D’Acci L., Lombardi P. (2010), MuSIC - A new Multi-scalar index for evaluating Sustainability in Cities, Amman (Jordan), The Second International Conference on Sustainable Architecture and Urban Development, 12-14/7/2010.

Di Tella R., MacCulloch R.J., Oswald A.J. (1999), "How Do Macroeconomic Fluctuations Affect Happiness?", mimeo, Harward Business School, Boston.

Diener E., Pavot W. (1993), "The Affective and Cognitive Context of Self-Reported Measures of Subjective Well-Being”, Social Indicators Researche 28(1), 1-20.

Diener E., Sandvik E., Seidlitz L., Diener M. (1993), “The Relationship between Income and Subjective Well-Being: Relative or Absolute?”, Social Indicators Research 28(3), pp. $195-223$

be irreversible. From an optimistic viewpoint we could think of these factors as part of the Negative Transitory Cycles, unless they become irreversible damages. 
Diener E., Diener M., Diener C. (1995), "Factors Predicting the Subjective Well-Being of Nations", Journal of Personality and Social Psychology, 69(5), pp. 851-864.

Duesenberry J. (1949), Income, saving and the Theory of Consumer Behavior, Harvard University Press, Cambridge.

Juster F.T., Courant P.N., Dow G.K. (1985), "A Conceptual Framework for the Analysis of Time Allocation Data", in Time, Goods, and Well-Being, Juster F.T., Stafford F.P., eds. Arbor A., Mich.: Institute for Social Research, University of Michigan, pp. 113-131.

Kahneman D., Snell J. (1990), "Predicting Utility”, in Hogarth R.M. (eds), Insights in Decision Making, University of Chicago Press, Chicago.

Kahneman D. (1994), "New Challenges to the Rationality Assumption", Journal of Institutional and Theoretical Economics, 150 (1994), 1, pp.18-36.

Kahneman D. (2003), "A Psychological Perspective on Economics”, The American Economic Review, 93 (2003), 2, pp. 162-168.

Kahneman D., Diener E., Shkade N., Stone A. (2003a), A survey method for characterizing daily life experience: The Day Reconstruction Method (DRM), Mimeo, Princeton University, Princeton (N.J.).

Kahneman D. (2004), "Toward National Well-Being Accounts", The American Economic Review, 94(2004), 2, pp. 429-434.

Kahneman D., Krueger A.B., Schkade D.A., Scharw N., Stone A. (2004a), A survey method for characterizing daily life experience: The Day Reconstruction Method (DRM), Science 306:5702, pp. 1776-1780.

Kahneman D. (2006), "Developments in the measurement of subjective well-being", The Journal of Economic Perspectives, 20, 3-24, 2006.

Kuznets S. (1962), "How To Judge Quality", The New Republic, October 20, 1962.

Kuznets S. (1934), "National Income, 1929-1932", 73rd US Congress, 2d session, Senate document no. 124, page 7 .

Easterlin R. (2001), "Income and Happiness: Towards a Unified Theory”, Economic Journal, July, n111, pp. 465-484.

Easterlin R. (2000), Income and Happiness: Towards a Unified Theory, Mimeo, Oxford University.

Easterlin R. (1995), "Will Raising the Incomes of All Increase the Happiness of All?", Journal of Economic Behaviour and Organization, 27(1), pp. 35-48.

Easterling R. (1974), "Does Economic Growth Improve the Human Lot? Some Empirical Evidence", in David P.A., Reder M.W. (eds), Nations and Households in Economic Growth: Essay in Honor of Moses Abroamowitz, Academic Press, New York, pp. 89125.

Frank R. (1999), Luxury Fever, Free Press, New York.

Frank R. (1985), "The Demand for Unobservable and Other Non-positional Goods", American Economic Review, 75(1), pp. 101-116.

Frey B.S., Benz M., Stutzer A. (2002), Introduction to Procedural Utility: Not only What, but also How Matters, Institute for Empirical Research in Economics, University of Zurich, Working Papers Series, n. 129, forthcoming in Journal of Institutional and Theoretical Economics.

Frey B.S., Stutzer A. (2002), Happiness and Economics, Princeton University Press, Princeton, [it. tr. (2006), Economia e felicità, Il Sole24ore, Milano].

Frey B.S, Luechinger S. (2007), Concepts of Happiness and their Meaurement, Metropolis, Verlag, pp. 219-237.

Frederick S., Loewenstein G. (1999), "Hedonic Adaptation”, in Kahneman D., Diener E., Scwarz N. (eds), Well-Being: The Foundations of Hedonic Psychology, Russel Sage Foudantions, New York, pp. 302-329.

Hanh F. (1984), "Su alcune difficoltà dell'economista utilitarista”, it. tr. in Sen A, Williams B. (eds), Utilitarismo e oltre, Il Saggiatore, Milano.

Headey B. and Wearing A. (1992), Understanding Happiness, Longman Cheshire, Melbourne, Australia.

Helson H. (1964), Adaptation-Level Theory: An Experimental and Systematic Approach to Behaviour, Harper \& Row, New York.

Hicks J.R. (1934), “A Reconsideration of the Theory of Value, I”, Economica, 1, pp. 52-75.

Houthakker H.S. (1950), "Revaled Preference and the Utility Function”, Economica, 17, pp. $275-$ 282.

Inglehart R., Foa R., Peterson P., Welzel C. (2008), "Development, Freedom, and Rising Happiness", Perspectives on Psychological Science, Volume 3-Number 4, pp. 264285. 
Inglearth R.F. (1990), Culture Shift in Advanced Industrial Society, Princeton University Press, Princeton (NJ).

Inkeles A., Diamond L. (1986), "Personal Development and National Development: A CrossCutlural Perspective”, in Szalai A., Andrews F.M. (eds), The Quality of Life: Comparative Studies, Institute for Social Research, University of Michigan, Ann Arbor (Mich.), pp. 73-109.

Irwin F.W. (1944), "The Realism of Expectations", Psychological Review, 51, pp. 120-126.

Kapteyn A., Wansbeek T. (1982), "Empirical evidence on preference formation" Journal of Economic Psychology, 2 (1982) 137-154.

Lane R.E. (1998), “The Joyless Market Economy”, in Ben-Ner A., Putterman L. (eds), Economics, Values, and Organization, Cambridge University Press, Cambridge (UK), pp. 461-488.

Leu R.E., Burri S., Priester T. (1997), Lebensqualitat und Armut in der Schweiz, Haupt, Bern.

Marks N., Abdallah S., Simms A, Thompson S. (2006), The Happy Planet Index, London: New Economics Foundation.

Marshall A. (1890), Principles of Economics, $8^{\text {th }}$ ed. (1920), Macmillan, London.

Myers D.G. (2000), "The Funds, Friends, and Faith of Happy People", American Psychologist, 55(1), pp. 56-67.

Modigliani F. (1949), Fluctuations in the Saving-Income Ratio: A Problem in Economic Forecasting, Conference on Research in Income and Wealth, New York.

Parducci A. (1995), Happiness, Pleasure, and Judgment: The Contextual Theory and Its Applications, Erlbaum, Hillsdale (NJ).

Pollak R.A. (1976), "Interdependent Preferences”, American Economic Review, 66(3), pp. 309320.

Pollak R.A. (1970), "Habit Formation and Dynamic Demand Functions", Journal of Political Economy, 78(4), pp. 745-763.

Robbins L. (1932), An Essay on the Nature and Significance of Economic Science, Macmillan, London, in Hausman D.M. (ed) (1984), The Philosophy of Economics: An Anthology, Cambridge University Press, New York.

Samuelson P.A. (1938), “A Note of the Pure Theory of Consumer's Behaviour”, Economica, 5(17), pp. 61-71.

Scitovsky T. (1976), The joyless economy, Oxford University Press, New York.

Sen A. (1987), On Ethics and Economics, Basil Blackwell, Oxford [it. tr. (2006), Etica ed economia, Laterza, Bari].

Simon H. (1982), Model of Bounded Rationality, MIT Press, Cambridge, [it. tr. (2001), Scienza economica e comportamento umano, Edizioni di Comunità, Torino].

Smith A. (1776), An Inquiry into the Nature and Causes of the Wealth of Nations, reprinted 1980, Deut and Sane, London, [it. tr. (1977), Indagine sulla natura e le cause della ricchezza delle nazioni, Oscar Mondadori, Milano].

Tversky A., Kahneman D. (1991), "Loss Aversion in Risksless Choice: A Reference-Dependent Model", Quarterly Journal of Economics, 106(4), pp- 1039-1061.

Uzawa H. (1960), "Preference and Rational Choice in the Theory of Consumption", in Kenneth J. Arrow, Simon Karlin, Peter Suppes (eds.), Mathematical Methods in the Social Sciences, Stanford University Press, Stanford (CA).

Van Praag B.M.S., Kapteyn A. (1973), "Further Evidence on the Individuai Welfare Function of Income: An Empirical Investigation in the Netherlands", European Economie Review, 4(1), pp. 33-62.

Van Praag B.M.S., Frijters P. (1999), “The Measurement of Welfare and Well-Being: The Leyden Approach", in Kahneman D., Diener E., Schwarz N. (eds.), Well-Being: The

Foundations of Hedonic Psychology, Russell Sage Foundation, New York, pp. 413-433.

Veblen T. (1899), The Theory of Leisure Class, Modern Library, New York.

Veenhoven R. (1991), “Is Happiness Relative?”, Social Indicators Research, 24(1), pp. 1-34.

http://www.worldvaluessurvey.org (World Values Survey)

http://worlddatabaseofhappiness.eur.nl (World Database of Happiness)

http://ec.europa.eu/public opinion/index en.htm (European Commission - Public Opinion)

https://www.cia.gov (CIA - Central Intelligence Agency)

http://www.un.org/en/rights (United Nations - Human Rights)

http://www.freedomhouse.org (Freedom House)

http://www.eiu.com (Economist Intelligence Unit)

http://www.enterprisesurveys.org (Enterprise Surveys)

http://puck.sourceoecd.org (OECD - Organization for Economic Co-operation and Development) http://hdr.undp.org (Human Development Reports) 